\title{
Spillover effects among financial institutions within Germany and the United Kingdom
}

Yaseen Ghulam $^{\mathrm{a}, \mathrm{b}}$ and Jana Doering ${ }^{\mathrm{c}}$

a. University of Portsmouth, Portsmouth Business School,

Economics and Finance Subject Group

Richmond Building, Portland Street, PO1 3DE, UK

Email: yaseen.ghulam@port.ac.uk

Phone: +442392844127

b. Al Yamamah University 7010 King Fahd Road,

Al Qirawan, Riyadh 13541, Saudi Arabia

c. University of Portsmouth, Portsmouth Business School,

Economics and Finance Subject Group

Richmond Building, Portland Street, PO1 3DE, UK 


\title{
Spillover Effects among Financial Institutions within Germany and the United Kingdom
}

\begin{abstract}
The recent financial crisis has shown that the relatively new interconnectedness of different types of institutions leads to a transmission of risk between them, therefore increasing systemic risk. This study investigates whether and to what extent financial institutions in Germany and the United Kingdom are exposed to risk transmission. To achieve this, a statedependent sensitivity value at risk approach is chosen. The empirical estimates suggest that hedge funds are the predominant source of risk spillovers, both in Germany and the UK, while they themselves receive very little risk spillovers. For the United Kingdom, it is shown that the magnitude of risk transmission is similar to that observed for Germany. However, UK insurance firms are less prone to spillovers from the hedge fund industry, but more affected by risks transmitted from banks, indicating possible implications for policy making. Overall, the increase in risk spillovers in volatile times is striking and suggests adapting future regulation to account for this phenomenon.
\end{abstract}

Keywords: Risk spillovers; Quantile regression; Financial institutions; Hedge funds; Statedependent sensitivity value at risk

JEL Classification: G01, G10, G24, G21, G28

* We thank an anonymous referee for several insightful comments. We alone are responsible for any errors. 


\section{Introduction}

The financial system is exposed to a risk higher than the sum of the individual risk exposures of its institutions (Thiele, 2014). Past regulation of the financial sector has failed to adequately account for this, as the rapid spreading of the recent financial crisis has shown. Solely characterising institutions as 'too big to fail' has proven insufficient and considering that they may also be too interconnected to fail is vital (Chen et al., 2014), because relationships between different types of financial institutions leads to the risk that a shock affecting one type of institution will be transmitted to other types through this interconnectedness (Adams et al., 2014a), thus generating additional systemic risk.

By recognizing the consequences of risk transmission between different institutions, a significant number of studies have been forthcoming in recent years, in particular, since the start of financial crisis. An example of the latter is when, Poirson and Schmittmann (2013) examined spillovers from the financial system of one country in the euro area to another, and Boyson et al. (2010) measured the dimension of spillover effects between different hedge funds styles. However, the interdependence between different types of institutions and thus the direction and the dimension of intra-country spillovers has historically been neglected (Gropp, 2014).

Empirical findings on intra-German spillovers are limited to spillovers among specific banks and the research does not account for the direction of the risk transmission (Poirson and Schmittmann, 2013). Correspondingly, research on spillovers within the UK financial system is limited to spillover effects from specific institutions to the remaining banking system (Goldsmith-Pinkham and Yorulmazer, 2010) and neglects those spillovers between different types of financial institutions. Broadly speaking, the studies that empirically 
investigated the linkage between different institutions focused only on the U.S. financial system (Billio et al., 2012; Adams et al., 2014a).

Our study fills this gap and investigates whether and to what extent financial institutions in Germany and the United Kingdom, respectively, are exposed to risk transmission from other types of financial institutions affected by a shock, thus estimating the direction and the dimension of spillovers between banks, insurances and hedge funds. The choice of Germany and the UK as a case study is based on two reasons. First, this choice helps us in understanding the dynamics of risks and its connectivity among some important components of the financial system in two historically different financial structures (bank oriented in Germany and market-oriented in the UK). Second, since hedge funds were found to cause the strongest spillover effects to other institutions during times of financial distress (Adams et al., 2014a), the different regulatory approaches of Germany and the United Kingdom ${ }^{1}$ render the application of the statistical models used in previous studies to two of the important European financial markets interesting.

In addition to above mentioned points, our study contributes to the existing empirical literature in many ways. First, the study provides a comparison between the two very large

\footnotetext{
${ }^{1}$ Before the financial crisis, regulation of alternative investment funds was country-specific, but the European Union decided on minimum regulatory standards in 2010. Whereas the UK only implemented these standards to preserve locational advantages and variety of products, Germany passed stricter legal regulation and, for example, banned private investors from hedge funds investments (Schulz, 2013). Similarly, the approaches to insurance firms' regulation differ between Germany and the UK. While they are both affected by capitalbased regulation on a European Union wide scale, the UK introduced little further restrictions, while Germany strictly limits insurers' business (Kaiser, 2008).
} 
and important countries by discussing in detail whether different regulatory approaches of these two countries further alter the interconnectedness. Second, our study in fact complements the study by Adams et al. (2014) who studied the direction and magnitude of risk from one institution to others for predominantly USA based financial institutions. Their coverage of the sectors was similar to ours and we believe that a European case study would help in either confirming or contrasting the earlier findings in a relatively different regulatory and economic environment settings as well as some differences in approaches to tackle financial crisis subsequently. In particular, the presence of larger universal banks in Germany further adds the value. Third, we discussed a number of policy options in understanding the interconnectivity. Our discussion of the limitations of our study and suggestions to improve the methodology further increase the utility of this study for future work in this area.

The analysis of our empirical estimates suggests that hedge funds are the predominant source of risk spillovers, both in Germany and the UK, while they themselves receive very little risk. The findings for Germany suggested that spillovers between insurances and banks are almost non-existent during tranquil market times, but increase significantly in times of financial distress. It was shown that insurance firms suffered less from spillovers than banks, highlighting that the German approach to insurance regulation, based on limiting exposure to specific types of assets and institutions as well as prohibiting noninsurance related businesses, might be a factor in curtailing their exposure. For the United Kingdom, it could be shown that the magnitude of risk transmission is similar to that observed for Germany. It was however striking that an increase in risk in the insurances sector has an overall stabilising effect on the banking sector even if the respective bank is distressed. Compared to Germany, insurance firms were less prone to spillovers from the 
hedge fund industry, but more affected by risks transmitted from banks. Overall, the increase in risk spillovers in volatile times was significant and suggests adapting future regulation to account for this.

In comparison to earlier studies and in particular Adams et al. (2014a), our findings are different at least on two fronts. First, broadly speaking, our estimates although confirms Adams findings, especially concerning hedge funds as the most important factor in transmitting risk to the rest of the financial sector but clearly, the extent is not as extreme as their results suggested and this highlight the fact that the European approach to stricter hedge fund regulation might be a factor in preventing the spread of risks between different sectors during times of financial distress. Second, our estimates show that the spillovers from hedge funds to the German insurance sector are significantly lower during times of financial distress indicating that they are less interconnected with the rest of the financial sector. This is largely due to the differences in the regulatory approaches concerning insurances in Germany. Insurances in Germany are regulated relating to their interconnectedness through upper limits with regards to specific asset groups and investments with one specific provider which helped in preventing an increase in systemic risk.

The remainder of the study is structured as follows: To contextualise the research question, the relevant literature is reviewed in the following section. After a definition of systemic risk, spillover effects and contagion, previous empirical approaches in the literature analysing the transmission of risk through spillovers is critically evaluated. The methodology employed to measure relevant risk spillovers is outlined in section 3 and the data of UK and German financial institutions that the study is based on is presented in 
section 4. Section 5 contains the detailed analysis of the data with regard to risk transmission, as well as the results and section 6 concludes.

\section{Review of Literature}

There are two distinct, yet interrelated dimensions to financial risk: first, a financial shock that simultaneously affects several institutions and prevents them from functioning properly and second, the possibility of difficulties of one financial institution being transmitted to originally largely unaffected institutions (Furfine, 2003). The detection of spillover effects is concerned with eliminating the influence of the former to measure the effects of the latter.

Contagion, defined as "significant increase in cross-market linkages after a shock to an individual country" (Dornbusch et al., 2000), and spillover effects have been used interchangeably (Cathcart et al., 2013). The literature, however, makes two differentiations. One strand considers the mere increase in co-movement in crises a spillover effect, which in return leads to contagion in severe cases (Alter and Beyer, 2013). While this definition explains the spreading of a shock between geographic regions (Dornbusch et al., 2000; Alter and Beyer, 2013, 2014), it fails to account for intra-country dependencies between different financial institutions. Other researchers defined contagion as "the portion of interdependence which is not accounted for by the spillover effect" (Cathcart et al., 2013). For the purpose of this study, spillover effects, defined as negative externalities in the form of a transmission of a shock from one institution to another beyond their exposure to common factors (De Bruyckere et al., 2013), are analysed. In the following, we provide summary and discuss some recent studies on this issue. A further detail in this regard is provided in Appendix A. 
Billio et al. (2012) investigated to what extent the U.S. financial sector is interrelated and found increased asymmetric connectedness, leading banks and insurance companies to more likely transmit shocks due to their asset illiquidity and the fact that, unlike hedge funds, they are not designed to withstand large losses (Billio et al., 2012).

Spillover effects and contagion in hedge fund returns have been investigated by Boyson et al. (2010) who argue that adverse shocks to speculators' funding liquidity lead to a reduction of leverage and thus of asset and funding liquidity. This creates a "self-reinforcing liquidity spiral" (Boyson et al., 2010) and hedge fund contagion. Their analysis provides evidence of a relation between liquidity shocks and hedge fund contagion, confirmed by Dudley and Nimalendran (2011) and expanded by Bussière et al. (2015). However, it has been shown that the interconnectedness of different financial institutions increased during the new millennium (Billio et al., 2012), indicating that transmission of risks might not be limited within one type (Bussière et al., 2015). This has historically been neglected (Bernal et al., 2014). When investigating the common exposure of hedge funds, Bussière et al. (2015) found that lately "commonality on hedge fund returns increased [...] and that hedge funds exposed to the common actor suffered from worse performance" mostly caused by an increased exposure to emerging market equities. However, while they stress that this may affect the financial stability and call for careful monitoring (Bussière et al., 2015), they do not investigate adverse implications of a spreading of risk from hedge funds to other institutions.

In terms of methodological developments, recently, a number of measures to capture interconnectedness have been developed, including the conditional value-at-risk (Adrian and Brunnermeier, 2008). Bernal et al. (2014) expand the $\Delta$ CoVaR methodology to analyse 
the contributions of the banking, insurance and other financial services sectors to systemic risk. They showed that the insurance sector was the largest contributor in the United States, whereas the Eurozone sector of other financial services was systemically the riskiest (Bernal et al., 2014). Their U.S. results were partially supported by Cummins and Weiss (2014) who found that non-core insurance activities contribute to systemic risk, whereas core functions do not as these are not sufficiently interconnected. This is supported by Allen and Gale (2007) who found that insurances and banks increasingly interact through credit risk transfer. However, the study measured the effects of adverse shocks to the financial sector on the real economy.

Contrary to that, other studies quantify the systemic risk within the financial industries themselves. Bierth et al. (2015) analyse the exposure and contribution of insurers. They contradict the results of Bernal et al. (2014) and found that, while low during tranquil times, the contribution to systemic risk of insurers worldwide peaked during the recent financial crisis due to their extreme leverage and that their interconnectedness exposed themselves to systemic risk (Bierth et al., 2015). To account for interconnectedness, spillover effects that they argue are not captured in the monthly data employed by Billio et al. (2012) and the simultaneity of risk transmission,

Adams et al. (2014a) measure the magnitude and direction of shocks from one institution to another for U.S. insurance companies, hedge funds, investment and commercial banks. Employing a state-dependent sensitivity value-at-risk model, they find that spillover effects are higher during volatile times. Their results further show that hedge funds are the main transmission channel for systemic risk. However, this analysis was based on U.S. data and may not be representative for the financial system of European countries. 


\section{Methodology}

The aim of this study is to explore spillover effects between different types of financial institutions, namely banks, insurances and hedge funds. To this end, we compiled and constructed a representative data, including return indices of banks and insurances, based in Germany and the UK respectively. Because of the fact that the German banking system is characterised by universal banks, retail and investment banks are not considered separately in this study. This decision is supported by the fact that "little evidence for risk spillovers between these two groups" was found (Adams et al., 2014b). As direct information on hedge funds and their risk exposure is limited (Bussière et al., 2015), a precalculated composite index will be employed. The HFRX Global Hedge Fund Index covers the complete range of hedge fund styles. The index weights are constructed using principal component (PC) analysis. The advantage of PC weights is that this linear combination preserves "the maximum possible proportion of the total variation in the original data set" (OECD, 2008) and the weights are derived from the correlation rather than the covariance matrix to not overweight institutions whose return series are characterised by a higher variance (Adams et al., 2014b).

Daily values-at-risk are calculated for the different indices individually.

$$
\widehat{\operatorname{VaR}}_{m}=\hat{\mu}_{m}+z \hat{\sigma}_{m, t},
$$

where $\hat{\mu}_{m}$ is the constant mean return of the institution. The VaR calculated employing unconditional rolling standard deviation and deduction of the relevant value for $z$ to represent the 5\%-quantile of the return distribution insufficiently captures the exposure. It decreases too late and fails to capture "the time-varying volatility of returns" (Adams et al., 
2014a). Therefore, the time-varying conditional standard deviation is employed, estimated using a model of the GARCH family, as this could best account for volatility clustering in return series. One of the advantage of the EGARCH model is that it estimates the logarithmic conditional variance, which is thus not dependent on non-negative regression coefficients (Brooks, 2014). Further, they are asymmetric and capture whether negative or positive shocks are more persistent to volatility. For equity returns it is argued that negative shocks lead to a higher volatility rise than positive shocks of comparable magnitudes (Brooks, 2014), which are economically explained as a leverage effect (Bollerslev et al., 1992). The captured asymmetry leads the $V a R$ series to closely follow the lower boundaries of the respective return series and therefore improves its sensitivity (Adams et al., 2014a).

Contrary to Adrian and Brunnermeier (2008), Adams et al. (2014a) propose a two-stage estimation of the spillover coefficient to test whether it depends on the state of the economy. While the 5\%-quantile of the return distribution represents the value-at-risk, low quantiles of said $\operatorname{VaR}$ distribution represent financial distress and higher quantiles represent tranquil times. Therefore, the institutions' individual fitted values-at-risk, $\widehat{V a R}_{m}$, are regressed against their own lags, the fitted values-at-risk of the other institutions and a set of control variables to account for common risk factors rooted in the macroeconomic development of a country to not mistakenly interpret co-movement of returns as spillover effects. The system of regression equations is estimated employing a two-stage quantile regression. During the first stage, instrumental variables for the exogenous variables are found using ordinary least square (OLS) estimation. This ensures that potentially endogenous regressors are replaced by instruments to eliminate simultaneous causality bias. It is expected that the lag of the value-at-risk of one institution is significant in predicting the level of the valueat-risk of that respective institution and can therefore serve as instruments. Comparable to 
two-stage least squares estimation, the right-hand side variables that are endogenous are regressed against their instrumental variable. Subsequently, the fitted values are employed in the quantile regression.

$$
\begin{aligned}
& \widehat{V a R}_{i, t, \theta}=\alpha_{1, \theta}+\beta_{1, \theta} \widehat{V a R}_{j, t}+\beta_{2, \theta} \widehat{V a R}_{k, t}+\beta_{3, \theta} \widehat{V a R}_{i, t-1}+\gamma_{1, \theta} \widehat{V a R}_{c, t}+ \\
& \gamma_{2, \theta} \widehat{V a R}_{r, t}+\gamma_{3, \theta} \widehat{V V R}_{n, t}+u_{i, t}
\end{aligned}
$$

$$
\begin{aligned}
& \widehat{V a R}_{j, t, \theta}=\alpha_{2, \theta}+\beta_{4, \theta} \widehat{V a R}_{i, t}+\beta_{5, \theta} \widehat{V V R}_{k, t}+\beta_{6, \theta} \widehat{V a R}_{j, t-1}+\gamma_{4, \theta} \widehat{V a R}_{c, t}+ \\
& \gamma_{5, \theta} \widehat{V a R}_{r, t}+\gamma_{6, \theta} \widehat{V a R}_{n, t}+u_{j, t}
\end{aligned}
$$

$$
\begin{aligned}
& \widehat{V a R}_{k, t, \theta}=\alpha_{3, \theta}+\beta_{7, \theta} \widehat{\operatorname{VaR}}_{i, t}+\beta_{8, \theta} \widehat{V a R}_{j, t}+\beta_{9, \theta} \widehat{\operatorname{VaR}}_{k, t-1}+\gamma_{7, \theta} \widehat{V a R}_{c, t}+ \\
& \gamma_{8, \theta} \widehat{V a R}_{r, t}+\gamma_{8, \theta} \widehat{V a R}_{n, t}+u_{k, t}
\end{aligned}
$$

$$
\begin{gathered}
\widehat{V a R}_{c, t, \theta}=\alpha_{4, \theta}+\partial_{1, \theta} \widehat{V a R}_{i, t}+\partial_{2, \theta} \widehat{V V R}_{j, t}+\partial_{3, \theta} \widehat{V a R}_{k, t}+\partial_{4, \theta} \widehat{V V R}_{c, t-1}+ \\
\partial_{5, \theta} \widehat{V a R}_{r, t}+\partial_{6, \theta} \widehat{V a R}_{n, t}+u_{c, t}
\end{gathered}
$$

$$
\begin{gathered}
\widehat{V a R}_{r, t, \theta}=\alpha_{5, \theta}+\partial_{7, \theta} \widehat{V V R}_{i, t}+\partial_{8, \theta} \widehat{V a R}_{j, t}+\partial_{9, \theta} \widehat{V V R}_{k, t}+\partial_{10, \theta} \widehat{V a R}_{r, t-1}+ \\
\partial_{11, \theta} \widehat{V a R}_{c, t}+\partial_{12, \theta} \widehat{V a R}_{n, t}+u_{r, t}
\end{gathered}
$$

$$
\begin{aligned}
& \widehat{V a R}_{n, t, \theta}=\alpha_{6, \theta}+\partial_{13, \theta} \widehat{V a R}_{i, t}+\partial_{14, \theta} \overline{\operatorname{VaR}}_{j, t}+\partial_{15, \theta} \widehat{\operatorname{VaR}}_{k, t}+\partial_{16, \theta} \widehat{V a R}_{n, t-1} \\
& +\partial_{17, \theta} \widehat{V a R}_{c, t}+\partial_{18, \theta} \widehat{V a R}_{r, t}+u_{n, t}
\end{aligned}
$$


$\widehat{V a R}_{i}, \widehat{V a R}_{j}$ and $\widehat{V a R}_{k}$ are the fitted values-at-risk of the individual institutional indices for banks, insurances and hedge funds, respectively. $\widehat{V a R}_{c}, \widehat{V a R}_{r}$ and $\widehat{V a R}_{n}$ are the fitted VaRs of the respective control variables. Although the $\partial$-coefficient vector is not of interest, the equations are included to allow for "feedback effects with [the] financial institutions" (Adams et al., 2014a).

The $\theta$-quantile describes the financial state of the receiving institution as the effect of a shock should be stronger if the institution is weakened (Adams et al., 2014a). At the 75\%quantile, the market is assumed to be tranquil, while it is volatile at the $12.5 \%$-quantile. Normal markets conditions are represented by the $50 \%$-quantile. While this specification introduces some arbitrariness to the model, it has very little effect on the results. Because it is expected that the spillovers are most striking for distressed market conditions, $10 \%$ - and 15\%-quantiles will also be employed as a robustness check. The spillover coefficient vectors are obtained from the individual $\beta$-coefficients.

$$
B_{i, \theta}=\left(\hat{\beta}_{1, \theta}, \hat{\beta}_{2, \theta}\right)
$$

$$
B_{j, \theta}=\left(\hat{\beta}_{4, \theta}, \hat{\beta}_{5, \theta}\right)
$$

$$
B_{k, \theta}=\left(\hat{\beta}_{7, \theta}, \hat{\beta}_{8, \theta}\right)
$$

These spillover coefficient vectors determine the risk transmission from one type of institution to another. The fitted SDSVaR is then obtained through the following equation.

$$
S \widehat{D S V a}_{\{i \mid j, k\}, t, \theta}=\alpha_{\theta}+\beta_{1, \theta} \widehat{\operatorname{VaR}}_{j, t}+\beta_{2, \theta} \widehat{\operatorname{VaR}}_{k, t}+\beta_{3, \theta} \widehat{\operatorname{VaR}}_{i, t-1}
$$


From these coefficients, it is possible to interpret the magnitude and the direction of spillovers depending on the state of the financial market.

\section{Data Sources}

The equity price series of German and UK banks and insurances were acquired from Thomson Reuters Datastream. For the analysis, returns were calculated from the stock price series and indices were determined employing principal component weightings.

The German insurance index contains data from six insurance firms that are publicly listed in Germany (Allianz, Münchener Rück, Hannover Rück, Talanx, Axa and Generali). For the UK, the insurance index consists of eight insurance firms, namely Amlin, Aviva, Chesnara, the Direct Line Insurance Group, the Esure Group, Helios Underwriting, Legal and General and the Novae Group.

The banking sector index for Germany consists of the data from nine banks including Deutsche Bank, Deutsche Postbank, Commerzbank, Wüstenrot and Württembergische, Aareal Bank, DVB Bank, IKB, Comdirect, Oldenburgische LB and DAB Bank. These banking firms experienced different levels of distress during the crisis, which geographically originated in the United States. Whereas the IKB was the first German bank to experience large difficulties in the course of the financial crisis and had to be rescued by the state and a consortium of banks (Hader et al., 2009), Talanx was only moderately affected by the crisis and constantly increased their annual profits (Schmitt, 2011). The UK banking index constitute seven banks including Aldermore Group, Barclays, the European 
Islamic Investment Bank, HSBC, Lloyds, the Royal Bank of Scotland, the Secure Trust Bank and Standard Chartered, which are all listed in the UK.

For hedge funds, the HFRX Global index provided by Hedge Fund Research and accessed through the Bloomberg database is employed. Whereas Adams et al. (2014b) argue that the HFRX indices generally are "not fully representative of the entire hedge fund universe", the HFRX Global Index aims at representing the composition of the hedge fund universe (UBS, 2012) and is therefore employed as a proxy. Because return data is not self-reported, the index does not suffer from self-selection bias (Adams et al., 2014a). While Adams et al. (2014a) employ the HFRX Equally Weighted Index, they indicate that results are unaffected if the Global Hedge Fund Index is employed instead. With a total of 45 constituents, all eligible hedge fund strategies are represented in the index. Due to the fact that it is only available from March $31^{\text {st }}, 2003$, it is the limiting factor of the time horizon of this study, which covers the period from March $31^{\text {st }}, 2003$ to July 27, 2015.

The control variables were obtained from two different data sources, namely Bloomberg and Börse Frankfurt. They are included in the regression to control for the macroeconomic development that is not intended to influence the regression results in that it could mistakenly be attributed to the influence of other institutions. For Germany and the UK, the SandP GSCI spot market commodity index is included as a "measure of general price movements and inflation in the world economy" ("Commodities performance overview", 2015). It is a composite index of the most liquid commodity futures that are included with weights according to "their respective world production quantities" (Goldman Sachs, 2015). Additionally, the DAX ex Financials 30 TR Index is included to cover the overall economic development of publicly listed companies that are not from the insurance, 
financial services or banking sector. The index covers "the largest and best-performing companies from the DAX index" (Deutsche Börse, 2015), which are not part of the respective industries. The last included control variable for Germany is the RX REIT index, an index that tracks the development of the three active German real estate investment trusts (G-REITs) (Börse Frankfurt, 2015). The act on the introduction of German Real Estate Stock Corporations with Listed Shares introduced German REITs in June 2007, but took retroactive effect as of January 2007 (Voss, 2008). For the UK, the FTSE non-Financial Index is included to cover non-financial firm performance and the FTSE EPRA/NAREIT Index controls for the performance of UK-listed real estate companies and REITs. All data sources are summarised and can be found in Table 1 .

[Insert table 1 about here]

\section{Empirical Results}

The results of the econometric analysis are summarised in the following way: Firstly, the created index series are presented, followed by the calculated values-at-risk for the institutional indices. Subsequently, to answer the research questions whether there are risk spillovers between different types of institutions in Germany and the United Kingdom and if so what direction these spillovers take, the spillover coefficients are analysed. Finally, possible applications of the spillover coefficient are illustrated by presenting the statedependent sensitivity value-at-risk.

\subsection{Index series}

Firstly, the equity price series of UK and German banks and insurances were transformed logarithmically and the first difference was taken to create a return series. Using principal 
component weights, indices were created from these return series ${ }^{2}$. Principal component analysis, rather than equal weights, was chosen to determine the weights of the individual institutions that the index is composed of. Even though Adams et al. (2014a) indicated that it does not qualitatively change their outcome, the data sample underlying this analysis suggests otherwise. As equal weights tend to assign higher weights to those series with high volatility (Adams et al., 2014b) and because, in this sample, those individual series with higher returns on average are more volatile, PC weights hence better represent the subsamples.

\subsection{Individual values-at-risk}

Following the index creation, individual values-at-risk were calculated according to formula (1). The standard deviation was determined using an $\operatorname{EGARCH}(1,1)$ because it has been suggested that this dimension sufficiently captures volatility in the variance (Brooks, 2014). For the model estimation, normally distributed errors were assumed. ${ }^{3}$ Because daily data on hedge fund returns is only available from April 2003 onward, the sample period covers 5,217 observations of each series from April 2, 2003 to July 27, $2015^{4}$.

\subsection{Estimation of the spillover coefficient vector}

The regression system (2-7) was estimated twice, once excluding the REIT indices as these are only available from 2007 onwards due to changes in the legislation on real estate

\footnotetext{
2 The indices created in this way, as well as the corresponding weights, are available upon request.

${ }^{3}$ However, results are not altered by the assumption of the error distribution or the dimension of the model, even a symmetric GARCH model leaves the results qualitatively unaltered (Adams et al., 2014a).

4 The individual index return series and the corresponding values-at-risk are available upon request.
} 
investment trusts (Voss, 2008) and once including the REIT indices as control variables, but reducing the sample period to the years 2007 to mid-2015.

Before analysing the spillover coefficients, it is important to highlight the improved information content of the spillover coefficients compared to solely expressing comovement through correlation coefficients. To do so, the correlation coefficients are presented in Table 2 for Germany and the UK, respectively. The observation period is subdivided into three subsamples. The first one covers the pre-crisis period from April 1, 2003 to August 8, 2007. The crisis period begins on August 9, 2007 when the credit crunch was pinpointed in Europe and ends after the second quarter of 2009. The third period is a post financial crisis period in which, however, the macroeconomic situation in Europe is still characterised by the euro area sovereign debt crisis, which continued to influence the behaviour of financial institutions in Germany and the United Kingdom (Popov and Van Horen, 2014).

[Insert table 2 about here]

For both countries, the co-movement between the returns of banks and insurances is stronger than the co-movement of these institutions with hedge funds. It is striking that, while the correlation coefficients generally increase from the pre-crisis to the crisis period in Germany, this is not the case for the United Kingdom, where they all decrease. Whereas the development after the financial crisis is ambiguous, the coefficients augment for all institutions in the UK. However, the strict definition of time periods introduces arbitrariness into the model and correlations are symmetric, the correlation coefficient do not allow for statistical inferences. Hence, spillover coefficients were estimated. 
It was first tested whether the first lags of the respective value-at-risk are valid instruments by regressing the $V a R$ levels against their lag and a constant. It can be seen from Table 3 that the lags of the values-at-risk are highly significant at one per cent level of significance in predicting the $\operatorname{VaR}$ of every institution. They therefore constitute valid instruments for the second step, in which the spillover coefficients were estimated employing quantile regression.

[Insert table 3 about here]

Table 4 and Table 5 present the estimated results for the $\beta$-spillover coefficients of equations (2) through (7), excluding REIT indices as control variables and for the different states of the financial market as defined by the respective quantile $\theta$. The corresponding results for the shorter observation period, but including the respective REIT index, are not qualitatively altered and can be found in appendices (Appendix B.1 and Appendix B.2). Comparably, it also became evident that the specification of the particular quantiles does not negatively affect the outcome, as the results are robust even for 10\%- and 15\%-quantiles representing economic distress of an institution.

Table 4 presents the regression coefficients for Germany. The estimates show that the interconnectedness in tranquil times is almost non-existent (below one hundredth of a per cent or even a slightly inverted relationship between banks and insurances and vice versa); only hedge funds display significant spillovers to the rest of the financial sector, mainly to insurances and to a lesser extent to banks in volatile market conditions. Every single spillover factor increases from a tranquil to a normal state of the market and this, overall, applies as well to the transition from normal to volatile market states, thus verifying the 
hypothesis of increased risk exposure in crisis times. Depending on the definition of the quantile for a volatile state of the market, the spillover effects from the hedge fund industry to the German insurance sector increase from $0.04 \%$ ( $75 \%$-quantile) to $0.3 \%$ (10\%quantile). The results are similar for spillovers from hedge funds to banks (albeit not significant), making hedge funds the most important source of risk spillovers within the German financial sector.

[Insert table 4 about here]

Another important observation is that risk spillovers to the German insurance sector are comparable to those of the banking sector in tranquil and normal times. The spillovers are, however, strikingly lower than those to the banking sector during times of financial distress. This result is different from that found by Adams et al. (2014a). It can be asserted that, while the U.S. insurance sector was badly affected by depreciations on credit derivatives as seen for the most prominent example of American International Group (AIG), the German insurance sector was largely untroubled by the financial crisis (Deutsche Bundesbank, 2009). Taking the results concerning their exposure to spillover effects into consideration, it becomes obvious that they are less interconnected with the rest of the financial sector. This is largely due to the differences in the regulatory approaches concerning banks and insurances in Germany. Insurances are regulated less with regard to capital requirements, but rather relating to their interconnectedness through upper limits with regards to, on the one hand, specific asset groups and investments with one specific provider on the other (Kaiser, 2008). Furthermore, through prohibiting business that is unrelated to the core function of insuring, German regulation, in contrast to U.S. regulation, prevents an increase 
in systemic risk as found by Cummins and Weiss (2014). It seems that this approach has proven successful during financial distress of insurances.

Compared to the correlation coefficients, it can be asserted that the increase in the influence of the value-at-risk of different institutions from tranquil to volatile times is much higher than that realised according to the correlation coefficients. It also becomes clear that it is important to account for the direction of the risk transmission: While the correlation between banks and hedge funds and insurances and hedge funds, respectively, is weaker than the link between the returns of banks and insurances, the results from the spillover estimation are twofold: Whereas the spillover from the hedge fund industry to banks and insurances is significant, especially when the latter are experiencing distress, the hedge fund industry barely experiences any change in its value-at-risk triggered by German banks and insurances. This is plausible because the hedge fund index is itself composed of international hedge funds and thus only limitedly affected by the risks of the German financial sector. It is shown that the restricting approach to regulation of hedge funds has not prevented immense spillovers to the German financial system.

Overall, spillovers are negligible when the market is tranquil, but are slightly higher during times when the market is in a normal state and increase significantly when the market becomes distressed. While hedge funds are least affected by spillovers, insurances are still less impacted than banks. It could be stated that measuring the direction of influence is of importance, which was most prominently shown for hedge funds. It again becomes evident for UK data that, while correlation coefficients are symmetric, the spillover coefficients indicate the direction from an originating institution to the receiving one. While the comovement, expressed as correlation, increases during crises times, this increase is more 
distinct when measured through risk spillovers comparing tranquil and volatile periods: Whereas an increase in the $V a R$ of banks only increases the $V a R$ of insurances by $0.01 \%$, the same relationship is magnified to around $0.04 \%$ during crisis times.

It becomes obvious that spillovers have about the same magnitude as in Germany. The relationship from the insurance to the banking sector, however, is an inverse one: If the value-at-risk of insurances increases, then that of banks decreases. Once again, hedge funds are the most important originator of $V a R$ spillovers and their influence increases drastically from tranquil to volatile states, but they experience very little risk spillovers from the UK insurances and banks. Compared to Germany, UK insurances suffered more significant spillovers from the banking sector, but less spillover from the hedge fund industry. The UK insurance sector itself is the only one of the five sectors analysed that does not show extreme persistence of shocks in volatile times. The remaining industries in Germany and the United Kingdom exhibit regression coefficients exceeding the value of one during volatile (and solely during volatile) times. This shows that, during financial distress, shocks to the $\operatorname{VaR}$ of the institutions propagate during the following days instead of dying away, increasing the systemic risk.

[Insert table 5 about here]

In an effort to perform some sensitivity analysis of our estimates with respect to choice of estimation method and stability/statistical significance of spillovers coefficients, we experimented with three other alternative approaches including GARCH, AVGARCH and $\mathrm{TGARCH}^{5}$. Broadly speaking, the conclusions and implications discussed above remained

\footnotetext{
5 The results can be obtained from the authors upon further request.
} 
qualitatively and quantitatively almost the same. All those coefficients which became significant with alternative estimation methods did not change the sign and significance level was around $10 \%$. More specifically, in utilising GARCH, for Germany, changes only affect the coefficients originating from hedge funds to insurances and banks for quantile $\theta$ $=0.75$ and quantile $\theta=0.5$. For the UK, newly significant variables were solely hedge fund originating spillovers to insurances and banks for $\theta=0.75$ and $\theta=0.5$. Other than that, there are merely some changes in the levels of significance in both directions.

In the case of using AVGARCH, for Germany, the spillover coefficient from hedge funds to insurances in normal times $(\theta=0.5)$ went from $10 \%$ significance level to insignificant. The spillover coefficient from insurances to bank became insignificant for one parameter of volatile times $(\theta=0.125)$, while becoming significant for another $(\theta=0.1)$. For the UK, only the spillover coefficient from hedge funds to banks in volatile times $(\theta=0.1)$ went from insignificant to significant at the $10 \%$ level, reinforcing the hypothesis of hedge funds as a main source of risk spillovers. Similarly, for TGARCH specification, two coefficients became insignificant (hedge funds and insurances) for $\theta=0.5$ and $\theta=0.125$ for Germany. For the UK, only change was hedge funds to banks for $\theta=0.1$.

To exemplify the interconnectedness and using our main method (EGARCH), two spillover coefficients are analysed in more detail in Figure 1 and Figure 2: the spillover coefficient from German banks to German insurances, has shown a comparatively modest increase for volatile times and the spillover coefficient from hedge funds to the UK banking industry, has shown a more extreme increase. They present the estimated spillover coefficient and the corresponding $95 \%$ confidence interval, as well as the coefficient and confidence interval that would have been estimated if OLS estimation had been employed instead of a 
quantile regression. It can be seen for both figures that this coefficient overestimates spillovers during tranquil times, while underestimating them during times of distress. This would lead to an inefficient allocation of capital during tranquil and normal times and an underestimation of risk during volatile times, increasing the risk of bankruptcy. Thus, the informational value gained through the state dependent sensitivity value-at-risk improves the risk analysis.

Excluding marginal values, Figure 1 shows that spillovers from German banks to insurances are of very little importance for medium to high quantiles of the distribution (tranquil and normal times), but increase to above $0.03 \%$ for lower, and especially very low, quantiles, for which insurers are regarded as being in distress. However, the coefficient remains comparatively low. This is very different for the spillover coefficient from hedge funds to the UK banking sector: While it fluctuates around zero for normal to tranquil times, it increases to above $0.6 \%$ during times, in which UK banks experience financial distress (Figure 2). It is visualised that the hedge fund industry supports liquidity when access to credit markets is easy, but amplifies crises when liquidity dries up and other institutions are in distress (Brunnermeier and Pederson, 2009).

Overall, the findings by Adams et al. (2014a) could be confirmed by European case study, especially concerning hedge funds as the most important factor in transmitting risk to the rest of the financial sector. However, the extent is not as extreme as their results suggested: The highest found spillover effect that originated from hedge funds was equal to $0.42 \%$ for UK banks during volatile times. Contrary to that, Adams et al. found spillovers with a magnitude of $0.71 \%$ to investment banks (2014a). It can thus be asserted that the European 
approach to stricter hedge fund regulation might be a factor in preventing the spread of risks between different sectors during times of financial distress.

\subsection{Application of the spillover coefficients}

The estimated spillover coefficients can be employed to estimate the state-dependent sensitivity value-at-risk ( $S D S V a R)$ for any institution depending on the state of the financial markets (tranquil, normal, volatile) and the value-at-risk of the other institutions. To do so, it must first be decided on the state of the institution at time $t$, depending on which, the quantile $\theta$ is set to a low value (distress) or higher value (prosperity). The value-at-risk can then be forecasted employing the coefficients as estimated in Table $4 \& 5$ above employing formula (11) repeated below again:

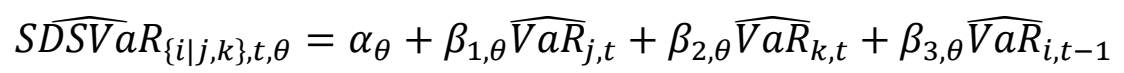

To estimate the SDSVaR as an example for German insurances during normal and volatile times, this equation would become:

$$
\begin{aligned}
\operatorname{SDSVa}_{\{\{j \mid i, k\}\}, t, 0.5}= & -0.0002+0.0079 * \widehat{V a R}_{i, t}+0.0682 * \widehat{V a R}_{k, t} \\
& +0.9445 * \widehat{V a R}_{j, t-1} \\
\operatorname{SDSVa}_{\{j \mid i, k\}, t, 0.125}= & 0.0003+0.0149 * \widehat{V a R}_{i, t}+0.2995 * \widehat{V a R}_{k, t} \\
& +1.0312 * \widehat{V a R}_{j, t-1}
\end{aligned}
$$

Unlike normal $V a R$ estimation, this accounts for both, the state of the institution in question and the spillover effects, through which the rest of the financial system exerts influence on 
the insurance sector, by including the relevant coefficients of other institutions for the respective quantile. As can be seen, the spillover coefficients are sufficiently small during normal times $(\theta=0.5)$ and increase significantly when insurances experience recessions $(\theta=0.1)$. This information can be crucial in predicting the transmission of a shock through the entire financial system of a country and thus is of prominent informational value for regulators. Furthermore, if the transmission channels through the financial system can be measured, the institutions themselves can react more adequately, anticipating the possible implications for them. The financial firms do not require explicit knowledge of their underlying ties with other institutions as these are represented by the spillover coefficients. Returning to the initial example of a hedge fund facing margin calls, this means that an insurer could estimate the impact on their risk, measured by the SDSVaR, in a timely manner without exactly being aware of the underlying interconnection.

There are, however, some limitations to the above mentioned approach: Due to the fact that daily data was chosen to measure immediate responses from other institutions, spillover effects that only occur more than one day after the original shock cannot be detected. Additionally, the proposed methodology cannot explain the underlying economic reasons for the transmission of risk, as this would require more detailed data from the hedge fund industry. Furthermore, it must be noted that spillover effects can only be detected if there has been a shock to the value-at-risk of the originating institution. If, for instance, insurances were to refrain from insuring banks' credit risk through credit derivatives, such as credit default swaps, the risk of banks would certainly be influenced (Allen and Gale, 2007), but this risk transmission would remain undetected because the insurance firms were not subject to a $V a R$ shock themselves. However, even if the risk transmission could not be 
depicted in its entirety, the remarkable magnitude of the measured spillovers and their important implications could be demonstrated in this study.

\section{Conclusion}

The fast spreading of the recent crisis from the U.S. subprime housing market to the financial sector and within the financial sector has shown that regulation has to some extent failed to account for the diverse dimensions of systemic risk. While the concept of 'too big to fail' has become widely accepted, the awareness of institutions being 'too interconnected to fail' has only recently been raised. This interconnectedness of financial institutions, however, possibly has extreme implications for the transmission of risk.

As previous findings suggested hedge funds to be the most relevant source of spillovers, it was expected that they will play a predominant role; however, more stringent regulation in Europe, and especially Germany, led to the expectation of a lower overall degree of risk transmission. Our estimates suggested that hedge funds are the predominant source of risk spillovers, both in Germany and the UK, while they receive very little risk spillovers themselves. This is in accordance with the large body of literature that identified hedge funds as a main driver in financial crises for other countries. Further findings for Germany suggested that spillovers between insurances and banks are almost non-existent during tranquil market times, but increase significantly in times of financial distress. It could be shown that insurances suffered less from spillovers than banks, highlighting that the German approach to insurance regulation might be a factor in curtailing their exposure to risk. For the UK, it could be shown that the magnitude of risk transmission is similar to that observed for Germany. It was, however, striking that an increase in risk in the insurances sector has an overall stabilising effect on the banking sector even if the respective bank is 
distressed. Compared to Germany, insurances were less prone to spillovers from the hedge fund industry, but were more affected by risks transmitted from banks. Overall, the increase in risk spillovers in volatile times recommends taking the interconnectedness of financial institutions as a source of additional risk seriously.

It is thus essential for regulation to allow for a systemic approach to the regulation of the financial sector. The extent of the spillovers calls for an adaptation of the measuring of risk within the institutions to more accurately depict the risk exposure. While first steps have been taken to account for the interconnectedness of institutions (see for example IAIS framework), showing that the concept of 'too complex to fail' is being integrated into insurance regulation, the current changes to regulation are heavily debatable.

The shortcomings should be the connecting factor for future research. To even more accurately depict the transmission of risk, a methodology that can account for spillovers without an initial shock to the value-at-risk of an institution could be developed. Additionally, it is advisable to conduct similar research in further countries, including an analysis of their regulation, so as to establish a best practice framework with regard to the regulation of the intertwined sectors. Furthermore, it is advisable that hedge fund regulation requires more detailed disclosure, as this would enable future researchers to examine the economic reasons underlying the immense risk transmission stemming from the hedge fund industry.

\section{References}

Adams, Z., Füss, R. and Gropp, R. 2014a. Spillover effects among financial institutions: 
A state-dependent sensitivity value-at-risk approach. Journal of Financial and Quantitative Analysis. 49(3): 575-598.

Adams, Z., Füss, R. and Gropp, R. 2014b. Supplementary internet appendix of Spillover effects among financial institutions: A state-dependent sensitivity value-at-risk approach. Journal of Financial and Quantitative Analysis. 49(3): 1-14.

Adrian, T. and Brunnermeier, M. K. 2008. CoVar. (Staff Report No. 348). New York City: Federal Reserve Bank of New York.

Allen, F. and Gale, D. 2007. Systemic risk and regulation. In M. Carey and R. M. Schulz (Eds.), The risks of financial institutions (pp.341-375). Chicago: Chicago University Press. Alter, A. and Beyer, A. 2013. The dynamics of spillover effects during the European sovereign debt turmoil. (ECB Working Paper No. 1558).

Bernal, O., Gnabo, J.-Y., and Guilmin, G. 2014. Assessing the contribution of banks, insurance and other financial services to systemic risk. Journal of Banking and Finance, 47: 270-287.

Bierth, C., Irresberger, F. and Weiß, G. N. F. 2015. Systemic risk of insurers around the globe. Journal of Banking and Finance, 55: 232-245.

Billio, M., Getmansky, M., Lo, A. W. and Pelizzon, L. 2012. Econometric measures of connectedness and systemic risk in the finance and insurance sectors. Journal of Financial Economics, 104(3): 535-559.

Bollerslev, T., Chou, R. Y. and Kroner, K. F. 1992. ARCH modeling in finance. A review of the theory and empirical evidence. Journal of Econometrics, 52: 5-59.

Börse Frankfurt (2015). RX REIT Index (Performance).

Boyson, N. M., Stahel, C. W. and Stulz, R. M. 2010. Hedge fund contagion and liquidity shocks. The Journal of Finance, 65(5): 1789-1816.

Brooks, C. (2014): Introductory Econometrics for Finance (3rd ed.). Cambridge: CUP. 
Brunnermeier, M. K. and Pedersen, L. H. 2009. Market liquidity and funding liquidity, Review of Financial Studies, 22(6): 2201-2238.

Bussière, M., Hoerova, M. and Klaus, B. 2015. Commonality in hedge fund returns: Driving factors and implications. Journal of Banking and Finance, 54: 266-280.

Cathcart, L., El-Jahel, L. and Jabbour, R. 2013. The determinants of European returns, spillovers and contagion. (Preprint submitted to the International Conference on Credit Risk Evaluation 2013).

Chen, H., Cummins, J. D. Viswanathan, K. S. and Weiss, M. A. 2014. Systemic risk and the interconnectedness between banks and insurers: an econometric analysis. Journal of Risk and Insurance, 81(3): 623-652.

Commodities performance overview. 2015. Standard and Poor Indices.

Cummins, J. D. and Weiss, M. A. 2014. Systemic risk and the U.S. insurance sector. The Journal of Risk and Insurance, 81(3): 489-527.

De Bruyckere, V., Gerhardt, M., Schepens, G. and Vander Vennet, R. 2013. Bank/sovereign risk spillovers in the European debt crisis. Journal of Banking and Finance, 37(12): 4793-4809.

Deutsche Börse. 2015. DAX ex Financials 30 (TR). Retrieved from the DAX Indices Deutsche Bundesbank. (2009). Finanzstabilitätsbericht 2009 [Financial Stability Report 2009].

Dornbusch, R., Park, Y. C. and Claessens, S. 2000. Contagion: Understanding how it spreads. The World Bank Research Observer, 15(2): 177-197.

Dudley, E. and Nimalendran, M. 2011. Margins and hedge fund contagion. Journal of Financial and Quantitative Analysis, 46(5): 1227-1257.

Furfine, C. H. 2003. Interbank exposures: Quantifying the risk of contagion. Journal of Money, Credit and Banking, 35(1): 111-128. 
Goldman Sachs. 2015. SandP GSCI commodity index.

Goldsmith-Pinkham, P. and Yorulmazer, T. 2010. Liquidity, bank runs, and bailouts: Spillover effects during the Northern Rock episode. Journal of Financial Services Research, 37(2/3): 83-98.

Gropp, R. 2014. How important are hedge funds in a crisis? FRBSF Economic Letter. 2014(11): 1-5.

Hader, J., Bryazgin, K. and Lieven, T. 2009. Folgen der Krise für die internationale Finanzwirtschaft [Consequences of the crisis for international corporate finance]. In R. Elschen and T. Lieven (Eds.), Der Werdegang der Krise. Von der Subprime- zur Systemkrise [The development of the crisis. From a subprime to a systemic crisis] (pp.145163). Wiesbaden: Gabler.

Kaiser, D. 2008. Within the International Mortgage Loan Crisis - The Position of German Banks and Insurances. In P. Cervinek (Ed.), Evropské financní systemy 2008 [European financial system 200] (pp.34-39). Brno: Masarykova univerzita.

Organisation for Economic Co-operation and Development (OECD). 2008. Handbook on constructing composite indicators. Methodology and user guide.

Poirson, H. and Schmittmann, J. 2013. Risk exposures and financial spillovers in tranquil and crisis times: Bank-level evidence. (IMF Working Paper 13/142).

Popov, A. and Van Horen, N. 2014. Exporting sovereign stress: evidence from syndicated bank lending during the euro area sovereign debt crisis. Review of Finance, 19(5): 18251866.

Schmitt, T. 2012. Talanx verkraftet Finanzkrise besser als Allianz und Munich Re [Talanx copes better with the financial crisis than Allianz and Munich Re]. Wirtschaftswoche.

Schulz, B. 2013. Hedgefonds droht straffe Regulierung [Hedge funds threatened by stricter regulation]. Frankfurter Allgemeine Zeitung. 
Thiele, A. 2014. Finanzaufsicht: Der Staat und die Finanzmärkte [Financial supervision: The State and financial markets]. Tübingen: Mohr Siebeck.UBS. (2012). Fact Sheet. UBSETG HFRX Global Hedge Fund (USD) SF-A.

Voss, J. 2008. Aufgaben und Chancen des German Real Estate Investment Trust (G-

REIT). Gezeigt bei Unternehmensimmobilien [Tasks and chances of the German real estate investment trust (G-REIT). Shown for business property]. Hamburg: Diplomica. 
Table 1: Data sources

\begin{tabular}{|c|c|c|}
\hline Series & Description & Source \\
\hline German bank index & $\begin{array}{l}\text { index of stock prices of banks listed in Germany (July 28, } 1995 \text { to July } 27 \text {, } \\
\text { 2015); constituents: Deutsche Bank, Deutsche Postbank, Commerzbank, } \\
\text { Wüstenrot and Württembergische, Aareal Bank, DVB Bank, IKB, Comdirect, } \\
\text { Oldenburgische LB and DAB Bank }\end{array}$ & Datastream \\
\hline German insurance index & $\begin{array}{l}\text { index of stock prices of insurances listed in Germany (July 28, } 1995 \text { to July 27, } \\
\text { 2015); constituents: Allianz, Münchener Rück, Hannover Rück, Talanx, Axa } \\
\text { and Generali }\end{array}$ & Datastream \\
\hline UK bank index & $\begin{array}{l}\text { index of stock prices of banks listed in the UK (July 28, } 1995 \text { to July 27, 2015); } \\
\text { constituents: Aldermore Group, Barclays, the European Islamic Investment } \\
\text { Bank, HSBC, Lloyds, the Royal Bank of Scotland, the Secure Trust Bank and } \\
\text { Standard Chartered }\end{array}$ & Datastream \\
\hline UK insurance index & $\begin{array}{l}\text { index of stock prices of insurances listed in the UK (July 28, } 1995 \text { to July } 27 \text {, } \\
\text { 2015); constituents: Amlin, Aviva, Chesnara, the Direct Line Insurance Group, } \\
\text { the Esure Group, Helios Underwriting, Legal and General and the Novae Group }\end{array}$ & Datastream \\
\hline HFRX Global Hedge Fund & hedge fund index comprising 45 active hedge funds that aims to represent the & Bloomberg \\
\hline Index & $\begin{array}{l}\text { hedge fund universe by covering the different hedge fund styles (March } 31^{\text {st }} \text {, } \\
2003 \text { to July } 27,2015 \text { ) }\end{array}$ & \\
\hline SandP GSCI TR & $\begin{array}{l}\text { index including most liquid commodity futures, world-production weighted } \\
\left.\text { (January } 3^{\text {rd }}, 2000 \text { to July } 27,2015\right) \text {, indicator for general price movements and } \\
\text { inflation }\end{array}$ & Bloomberg \\
\hline DAX ex Financials 30 TR & $\begin{array}{l}\text { return-based index comprising the } 30 \text { largest and best-performing companies } \\
\text { excluding such from the financial services, banking and insurance sectors }\end{array}$ & Bloomberg \\
\hline X REIT Index & $\begin{array}{l}\text { performance index comprised of the three currently existing German real estate } \\
\text { investment trusts (November, } 7^{\text {th }}, 2007 \text { to July } 27,2015 \text { ) }\end{array}$ & $\begin{array}{l}\text { Börse Frankfurt, } \\
\text { http://www.boerse- } \\
\text { frankfurt.de/en/equiti } \\
\text { es/indices } \\
\text { /rx+reit+index+perfo } \\
\text { rmance+DE00 } \\
\text { 0A0MEN66, } \\
\text { accessed August, 27 } \\
2015\end{array}$ \\
\hline FTSE Non-Financial Index & $\begin{array}{l}\text { FTSE all-share index excluding companies from financial services, banking and } \\
\text { insurance sectors (January } 4^{\text {th }}, 2000 \text { to July } 27,2015 \text { ), }\end{array}$ & Bloomberg \\
\hline FTSE EPRA/NAREIT Index & $\begin{array}{l}\text { tracks performance of } 33 \text { real estate companies and REITs listed on the London } \\
\text { Stock Exchange (January } 1^{\text {st }}, 2007 \text { to July } 27,2015 \text { ) }\end{array}$ & Bloomberg \\
\hline
\end{tabular}


Table 2: Correlation Coefficients

\begin{tabular}{|c|c|c|c|c|}
\hline & & Banks & Insurances & Hedge funds \\
\hline \multicolumn{5}{|l|}{ Germany } \\
\hline \multirow[t]{2}{*}{ pre-crisis period } & Banks & - & 0.7249 & 0.5358 \\
\hline & Hedge funds & 0.5358 & 0.4843 & - \\
\hline \multirow[t]{2}{*}{ crisis period } & Banks & - & 0.7904 & 0.5507 \\
\hline & Insurances & 0.7904 & - & 0.4697 \\
\hline \multirow[t]{3}{*}{ post-crisis period } & Banks & - & 0.7989 & 0.4924 \\
\hline & Insurances & 0.7989 & - & 0.5306 \\
\hline & Hedge funds & 0.4924 & 0.5306 & - \\
\hline \multicolumn{5}{|l|}{ United Kingdom } \\
\hline pre-crisis period & Banks & - & 0.6929 & 0.4775 \\
\hline \multirow{2}{*}{ crisis period } & Insurances & 0.6859 & - & 0.3512 \\
\hline & Hedge funds & 0.3513 & 0.3512 & - \\
\hline \multirow[t]{3}{*}{ post-crisis period } & Banks & - & 0.7134 & 0.5041 \\
\hline & Insurances & 0.7134 & - & 0.5220 \\
\hline & Hedge funds & 0.5041 & 0.5220 & - \\
\hline
\end{tabular}


Table 1: Instruments OLS Regression

\begin{tabular}{|c|c|}
\hline Institutions/parameters & Estimates \\
\hline Germany & 1882 d.o.f. \\
\hline Banks & $V a R_{i, t}=\alpha_{0}+\alpha_{1} V a R_{i, t-1}$ \\
\hline Intercept & $-0.0002 * *(-2.51)$ \\
\hline$V a R_{i, t-1}$ & $0.9912 * * *(323.70)$ \\
\hline Insurances & $V a R_{j, t}=\alpha_{0}+\alpha_{1} V a R_{j, t-1}$ \\
\hline Intercept & $-0.0002^{* * *}(-3.55)$ \\
\hline$V a R_{j, t-1}$ & $0.9852^{* * *}(251.56)$ \\
\hline Hedge funds & $\operatorname{VaR}_{k, t}=\alpha_{0}+\alpha_{1} \operatorname{VaR}_{k, t-1}$ \\
\hline Intercept & $0.0001^{* * *}(-4.25)$ \\
\hline$V a R_{k, t-1}$ & $0.9776 * * *(205.31)$ \\
\hline United Kingdom & 1882 d.o.f. \\
\hline Banks & $V a R_{i, t}=\alpha_{0}+\alpha_{1} V a R_{i, t-1}$ \\
\hline Intercept & $-0.0002^{* *}(-2.60)$ \\
\hline$V a R_{i, t-1}$ & $0.9893 * * *(292.87)$ \\
\hline Insurances & $V a R_{j, t}=\alpha_{0}+\alpha_{1} V a R_{j, t-1}$ \\
\hline Intercept & $-0.0002^{* *}(-3.26)$ \\
\hline $\operatorname{VaR}_{j, t-1}$ & $0.9853^{* * *}(251.14)$ \\
\hline Hedge funds & $V a R_{k, t}=\alpha_{0}+\alpha_{1} V a R_{k, t-1}$ \\
\hline Intercept & $0.0001 * * *(-4.25)$ \\
\hline $\operatorname{VaR}_{k, t-1}$ & $0.9776^{* * *}(205.31)$ \\
\hline
\end{tabular}


Table 4: Spillover Coefficients for Germany

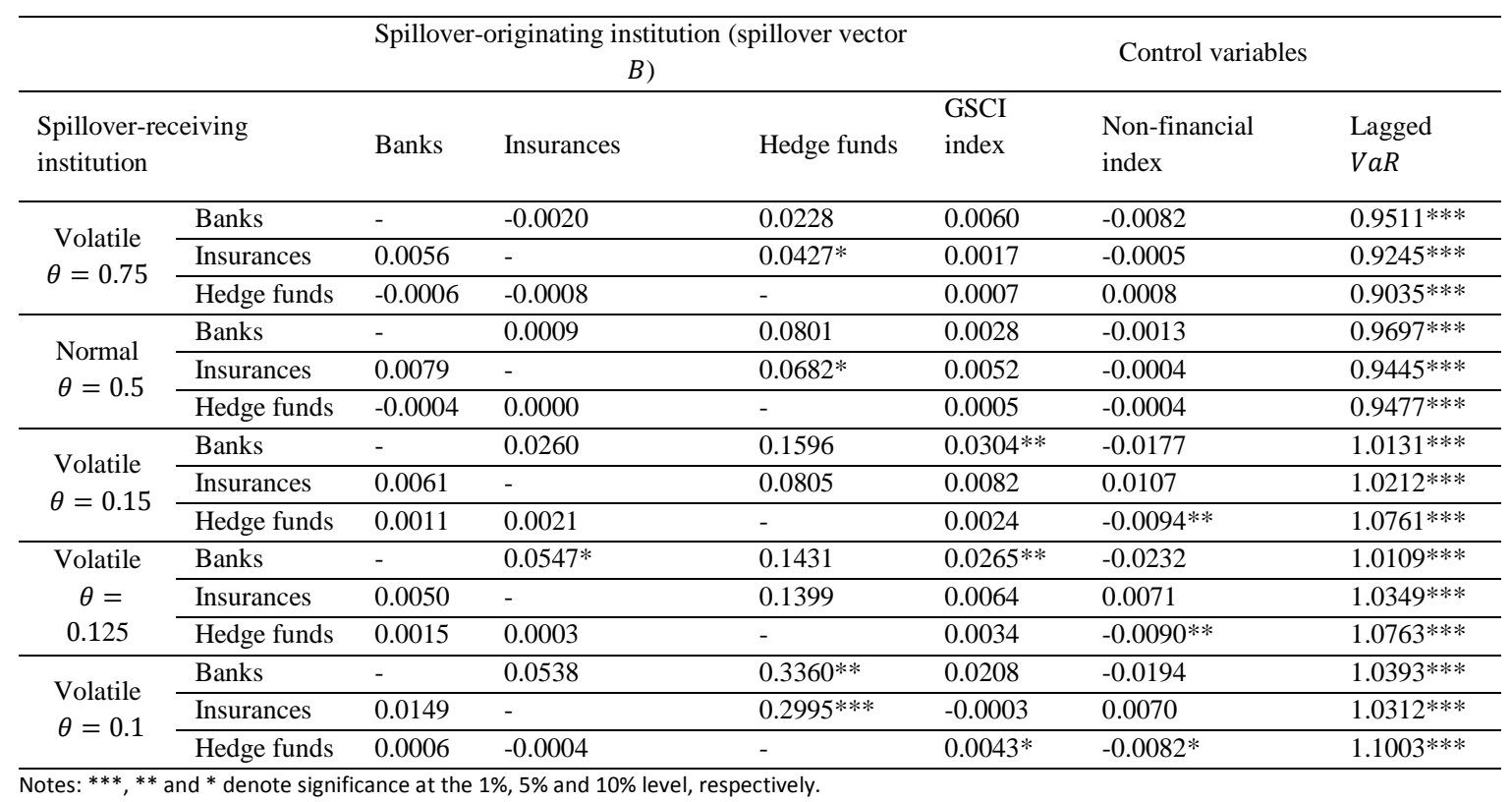


Table 5: Spillover Coefficients for the United Kingdom

\begin{tabular}{|c|c|c|c|c|c|c|c|}
\hline & & \multicolumn{3}{|c|}{$\begin{array}{l}\text { Spillover-originating institution (spillover } \\
\text { vector } B \text { ) }\end{array}$} & \multicolumn{3}{|c|}{ Control variables } \\
\hline \multicolumn{2}{|c|}{ Spillover-receiving institution } & Banks & Insurances & Hedge funds & $\begin{array}{l}\text { GSCI } \\
\text { index }\end{array}$ & $\begin{array}{l}\text { Non-financial } \\
\text { index }\end{array}$ & $\begin{array}{l}\text { Lagged } \\
\operatorname{VaR}\end{array}$ \\
\hline \multirow{2}{*}{$\begin{array}{l}\text { Tranquil } \theta= \\
\quad 0.75\end{array}$} & Banks & - & -0.0020 & 0.0444 & 0.0001 & 0.0155 & $0.9334 * * *$ \\
\hline & Insurances & $0.0115^{* *}$ & - & 0.0387 & -0.0067 & 0.0064 & $0.9078^{* * * *}$ \\
\hline \multirow{3}{*}{$\begin{array}{c}\text { Normal } \theta= \\
0.5\end{array}$} & Banks & - & -0.0028 & 0.0551 & 0.0112 & 0.0083 & $0.9645 * * *$ \\
\hline & Insurances & $0.0296 * * *$ & - & 0.1032 & 0.0032 & -0.0043 & $0.9138^{* * * *}$ \\
\hline & $\begin{array}{l}\text { Hedge } \\
\text { funds }\end{array}$ & -0.0007 & 0.0009 & - & 0.0005 & 0.0000 & $0.9415^{* * *}$ \\
\hline \multirow{3}{*}{$\begin{array}{l}\text { Volatile } \theta= \\
0.125\end{array}$} & Banks & - & $-0.0394 * * *$ & $0.4210^{* *}$ & $0.0526^{* * *}$ & -0.0312 & $1.0810^{* * * *}$ \\
\hline & Insurances & $0.0365 * *$ & - & 0.1101 & 0.0172 & 0.0318 & $0.9755^{* * *} *$ \\
\hline & $\begin{array}{l}\text { Hedge } \\
\text { funds }\end{array}$ & -0.0017 & 0.0006 & - & 0.0039 & -0.0016 & $1.0737 * * *$ \\
\hline \multirow{3}{*}{$\begin{array}{l}\text { Volatile } \theta= \\
0.1\end{array}$} & Banks & - & $-0.0672 * *$ & 0.3607 & $0.0528^{* *}$ & 0.0125 & $1.0942 * * *$ \\
\hline & Insurances & $0.0387 *$ & - & 0.1276 & 0.0252 & 0.0141 & $0.9911^{* * * *}$ \\
\hline & $\begin{array}{l}\text { Hedge } \\
\text { funds }\end{array}$ & -0.0018 & 0.0013 & - & 0.0039 & -0.0033 & $1.0855^{* * *}$ \\
\hline
\end{tabular}

Notes: ${ }^{* *},{ }^{* *}$ and ${ }^{*}$ denote significance at the $1 \%, 5 \%$ and $10 \%$ level, respectively. 
Figure 1: Spillover Coefficients from German Banks to German Insurances

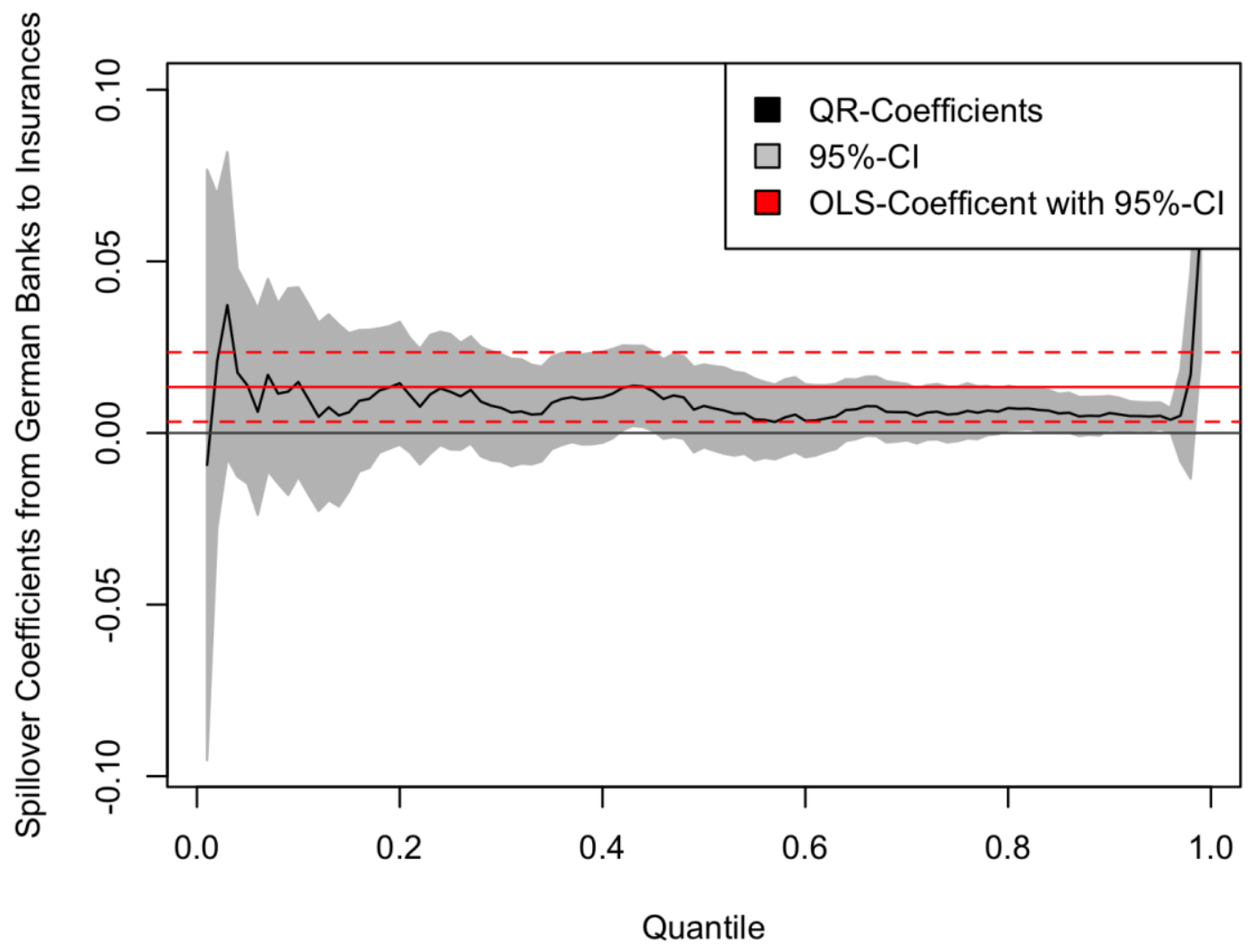


Figure 2: Spillover Coefficients from Hedge Funds to UK Banks

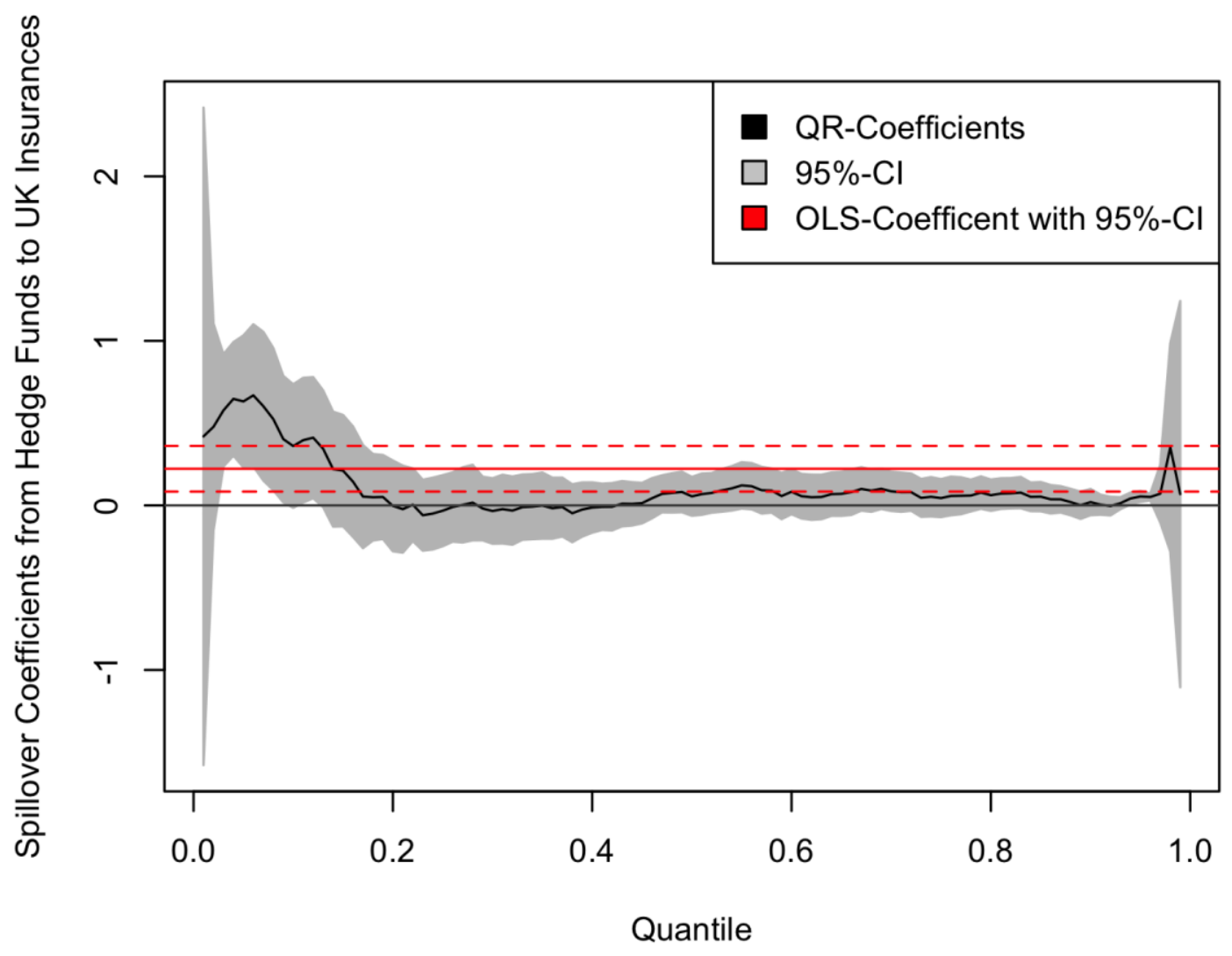




\section{Appendix A. Summary table of the literature spillovers (in alphabetical order)}

\begin{tabular}{|c|c|c|c|c|c|}
\hline Study & Research question & Theory & Data sample & Analytical method & Main findings \\
\hline $\begin{array}{l}\text { Adams et al. } \\
(2014 a)\end{array}$ & $\begin{array}{l}\text { Quantification of the } \\
\text { direction, size and } \\
\text { duration of risk } \\
\text { spillovers among } \\
\text { financial institutions } \\
\text { depending on the } \\
\text { state of financial } \\
\text { markets }\end{array}$ & $\begin{array}{l}\text { Most risk } \\
\text { measures } \\
\text { underestimate } \\
\text { systemic risk, but } \\
\text { a state-dependent } \\
\text { value at risk is } \\
\text { able to reveal risk } \\
\text { spillovers. }\end{array}$ & $\begin{array}{l}\text { Daily data } \\
\text { (April 2, 2003 } \\
\text { to December } \\
31,2010 \text { ) for } \\
\text { banks and } \\
\text { insurances, } \\
\text { Hedge Fund } \\
\text { Research } \\
\text { Equally } \\
\text { Weighted } \\
\text { Strategies } \\
\text { Index } \\
\end{array}$ & $\begin{array}{l}\text { Independent } \mathrm{VaR} \\
\text { estimation for all } \\
\text { institutions, } \\
\text { regression of the } \mathrm{VaR} \\
\text { against its own lag } \\
\text { and VaR of other } \\
\text { institutions and } \\
\text { control variables in a } \\
\text { two-stage quantile } \\
\text { regression }\end{array}$ & $\begin{array}{l}\text { Spillover effects are small } \\
\text { during normal periods, but } \\
\text { high when the market is } \\
\text { volatile. Most shocks are } \\
\text { transmitted through } \\
\text { commercial banks and } \\
\text { predominantly hedge funds. }\end{array}$ \\
\hline $\begin{array}{l}\text { Adrian \& } \\
\text { Brunnermeier } \\
(2008)\end{array}$ & $\begin{array}{l}\text { How to measure and } \\
\text { predict systemic } \\
\text { risk? }\end{array}$ & $\begin{array}{l}\text { "[T]he difference } \\
\text { between the } \\
\text { conditional value } \\
\text { at risk (CoVaR) } \\
\text { of the financial } \\
\text { system } \\
\text { conditional on an } \\
\text { institution being } \\
\text { in distress and } \\
\text { the CoVaR } \\
\text { conditional on } \\
\text { the median state } \\
\text { of the institution" }\end{array}$ & $\begin{array}{l}\text { Weekly equity } \\
\text { returns of all } \\
\text { commercial } \\
\text { banks, broker- } \\
\text { dealers, } \\
\text { insurance and } \\
\text { real estate } \\
\text { companies } \\
\text { publicly listed } \\
\text { in the U.S. } \\
\text { (1971Q1 to } \\
\text { 2013Q2) }\end{array}$ & $\begin{array}{l}\text { Estimation of } \\
\Delta C o V a R, \text { panel } \\
\text { regression and out- } \\
\text { of-sample forecasts }\end{array}$ & $\begin{array}{l}\Delta C o V a R \text { successfully } \\
\text { measures systemic risk }\end{array}$ \\
\hline $\begin{array}{l}\text { Alter \& Beyer } \\
(2014)\end{array}$ & $\begin{array}{l}\text { What are "the } \\
\text { dynamics of } \\
\text { financial contagion } \\
\text { among sovereigns } \\
\text { and banks and [...] } \\
\text { the main contributors } \\
\text { to contagion within } \\
\text { the Eurozone" (Alter } \\
\& \text { Beyer, 2014, } \\
\text { p.135)? }\end{array}$ & $\begin{array}{l}\text { Spillovers among } \\
\text { European } \\
\text { sovereigns and } \\
\text { banks are caused } \\
\text { by several } \\
\text { transmission } \\
\text { mechanisms } \\
\text { (joint monetary } \\
\text { policy, shared } \\
\text { default risk, } \\
\text { sovereign-banks } \\
\text { feedback loops). }\end{array}$ & $\begin{array}{l}\text { Log-returns of } \\
\text { daily CDS } \\
\text { spreads from } \\
\text { banks and } \\
\text { sovereigns for } \\
\text { eleven euro } \\
\text { area countries } \\
\text { (October 2009 } \\
\text { to July 2012) }\end{array}$ & $\begin{array}{l}\text { Vector autoregressive } \\
\text { model with } \\
\text { exogenous variables } \\
\text { (control variables) } \\
\text { and generalised } \\
\text { impulse response } \\
\text { functions to measure } \\
\text { interaction of the } \\
\text { CDS spreads and } \\
\text { their included lags } \\
\text { and estimate a } \\
\text { contagion index }\end{array}$ & $\begin{array}{l}\text { The measured contagion } \\
\text { index shows strong co- } \\
\text { movement for banks and } \\
\text { sovereigns, which were both } \\
\text { stable within a certain } \\
\text { interval and increasing } \\
\text { contagion for banks-to- } \\
\text { sovereigns and sovereigns- } \\
\text { to-banks indices, indicating } \\
\text { that feedback loops } \\
\text { intensified. }\end{array}$ \\
\hline $\begin{array}{l}\text { Bernal et al. } \\
(2014)\end{array}$ & $\begin{array}{l}\text { To what extent does } \\
\text { distress within the } \\
\text { banking, insurance } \\
\text { and other financial } \\
\text { services sector } \\
\text { contribute to } \\
\text { systemic risk? }\end{array}$ & ---- & $\begin{array}{l}\text { Daily data } \\
\text { from } \\
\text { September } 21 \text {, } \\
2004 \text { to March } \\
16,2012 \text { for } \\
\text { the United } \\
\text { States and the } \\
\text { Eurozone }\end{array}$ & $\begin{array}{l}\Delta C o V a R \text { systemic } \\
\text { risk measure } \\
\text { introduced by Adrian } \\
\text { and Brunnermeier } \\
\text { extended to include } \\
\text { the Kolmogorov- } \\
\text { Smirnov test based on } \\
\text { bootstrapping }\end{array}$ & $\begin{array}{l}\text { All three analysed financial } \\
\text { sectors (banking, insurance, } \\
\text { and other financial services) } \\
\text { contribute significantly to } \\
\text { systemic risk in the } \\
\text { Eurozone and the US. In } \\
\text { times of distress, the other } \\
\text { financial services sector } \\
\text { contributes most to systemic } \\
\text { risk in the Eurozone } \\
\text { followed by the banking } \\
\text { sector. In the US, however, } \\
\text { the insurance sector was } \\
\text { found to contribute most, } \\
\text { while the banking sector } \\
\text { contributed least to systemic } \\
\text { risk. }\end{array}$ \\
\hline $\begin{array}{l}\text { Bierth et al. } \\
(2015)\end{array}$ & $\begin{array}{l}\text { Are life and non-life } \\
\text { insurers more } \\
\text { heavily exposed to } \\
\text { and/or contributing } \\
\text { to systemic risk due } \\
\text { to their } \\
\text { interconnectedness } \\
\text { with the rest of the } \\
\text { financial sector? }\end{array}$ & ----- & $\begin{array}{l}\text { Data from } 253 \\
\text { large } \\
\text { international } \\
\text { life and non- } \\
\text { life insurance } \\
\text { firms for the } \\
\text { period } 2000 \text { to } \\
2012\end{array}$ & $\begin{array}{l}\text { Estimation of } \\
\Delta C o V a R, \text { marginal } \\
\text { expected shortfall and } \\
\text { systemic risk index as } \\
\text { systemic risk } \\
\text { measures, which are } \\
\text { then regressed against } \\
\text { factors that make an } \\
\text { insurer systemically } \\
\text { relevant, namely size, } \\
\text { capital structure, non- } \\
\text { core activities and } \\
\text { interconnectedness }\end{array}$ & $\begin{array}{l}\text { Systemic risk in the } \\
\text { insurance sector is overall } \\
\text { small compared to previous } \\
\text { findings concerning banks, } \\
\text { but during the financial } \\
\text { crisis, systemic risk was } \\
\text { significantly augmented by } \\
\text { insurers. The most } \\
\text { important factors were the } \\
\text { insurer's leverage and } \\
\text { interconnectedness. }\end{array}$ \\
\hline
\end{tabular}




\begin{tabular}{|c|c|c|c|c|c|}
\hline $\begin{array}{l}\text { Billio et al. } \\
(2012)\end{array}$ & $\begin{array}{l}\text { To what extent are } \\
\text { hedge funds, banks, } \\
\text { investment banks } \\
\text { and insurance } \\
\text { companies } \\
\text { interrelated? }\end{array}$ & $\begin{array}{l}\text { The } \\
\text { transformation of } \\
\text { the financial and } \\
\text { insurance sector } \\
\text { and the increased } \\
\text { business ties } \\
\text { between different } \\
\text { institutions } \\
\text { increases shock } \\
\text { transmission. }\end{array}$ & $\begin{array}{l}\text { Monthly } \\
\text { equity returns } \\
\text { for U.S. } \\
\text { banks, broker- } \\
\text { dealers and } \\
\text { insurances, } \\
\text { monthly } \\
\text { reported net- } \\
\text { of-fee fund } \\
\text { returns for } \\
\text { hedge funds } \\
\text { (January } 1994 \\
\text { to December } \\
\text { 2008) }\end{array}$ & $\begin{array}{l}\text { Principal component } \\
\text { analysis and linear } \\
\text { and nonlinear } \\
\text { Granger-causality } \\
\text { tests }\end{array}$ & $\begin{array}{l}\text { Increasing } \\
\text { interconnectedness of the } \\
\text { four sectors, likely } \\
\text { increasing systemic risk, } \\
\text { shock transmission from } \\
\text { banks and insurances is } \\
\text { strongest }\end{array}$ \\
\hline $\begin{array}{l}\text { Boyson et al. } \\
(2010)\end{array}$ & $\begin{array}{l}\text { Is contagion among } \\
\text { different styles of } \\
\text { hedge funds present? }\end{array}$ & $\begin{array}{l}\text { Shocks to asset } \\
\text { and hedge fund } \\
\text { liquidity } \\
\text { ultimately lead to } \\
\text { hedge fund } \\
\text { contagion. }\end{array}$ & $\begin{array}{l}\text { Equally } \\
\text { weighted } \\
\text { monthly } \\
\text { hedge fund } \\
\text { index data } \\
\text { (January } 1990 \\
\text { to October } \\
\text { 2008) for } \\
\text { different } \\
\text { hedge fund } \\
\text { styles }\end{array}$ & $\begin{array}{l}\text { Regression of returns } \\
\text { in an AR(1) model to } \\
\text { account for } \\
\text { autocorrelation and } \\
\text { common risk factors, } \\
\text { filtered residuals in } \\
\text { quantile regression } \\
\text { and parametric test of } \\
\text { contagion, } \\
\text { multinomial } \\
\text { regression analysis to } \\
\text { measure intensity of } \\
\text { contagion }\end{array}$ & $\begin{array}{l}\text { Observation of clustering in } \\
\text { hedge fund worst returns } \\
\text { unexplained by common risk } \\
\text { factors, thus hedge fund } \\
\text { contagion linked to liquidity } \\
\text { shocks that was strongest in } \\
2008\end{array}$ \\
\hline $\begin{array}{l}\text { Bussière et al. } \\
\text { (2015) }\end{array}$ & $\begin{array}{l}\text { What are the driving } \\
\text { factors of hedge } \\
\text { funds' commonality } \\
\text { and how does the } \\
\text { degree of } \\
\text { commonality affect } \\
\text { the funds' risk } \\
\text { exposure? }\end{array}$ & ----- & $\begin{array}{l}\text { Hedge fund } \\
\text { returns } \\
\text { between } \\
\text { January } 1994 \\
\text { and June } 2009 \\
\text { with a } \\
\text { database of } \\
\text { about } 6400 \\
\text { hedge funds }\end{array}$ & $\begin{array}{l}\text { PCA to measure the } \\
\text { commonality in } \\
\text { hedge funds, ranking } \\
\text { of hedge funds into } \\
\text { deciles according to } \\
\text { their loading on the } \\
\text { first principal } \\
\text { component, stepwise } \\
\text { regression of excess } \\
\text { returns on } 12 \text { risk } \\
\text { factors }\end{array}$ & $\begin{array}{ll}\text { Commonality in hedge funds } \\
\text { increased from } 2003 \text { to } \\
\text { 2006. } & \text { high } \\
& \text { commonality } \\
& \text { funds: exposed to } \\
& \text { equity-oriented } \\
& \text { risk factors, } \\
& \text { higher downside } \\
& \text { risk, higher } \\
& \text { illiquidity risk, } \\
& \text { less } \\
& \text { diversification } \\
& \text { benefits } \\
& \text { low commonality } \\
& \text { funds: small or } \\
& \text { no exposure to } \\
& \text { equity-oriented } \\
& \text { risk-factors }\end{array}$ \\
\hline $\begin{array}{l}\text { Chen et al. } \\
\text { (2013) }\end{array}$ & $\begin{array}{l}\text { Is there Granger } \\
\text { causality between } \\
\text { bank and insurance } \\
\text { risks? }\end{array}$ & ----- & $\begin{array}{l}\text { Daily data on } \\
\text { CDS spreads, } \\
\text { intraday data } \\
\text { on stock prices } \\
\text { of } 11 \\
\text { insurances and } \\
22 \text { banks from } \\
\text { February } 2002 \\
\text { to May } 2008 \\
\end{array}$ & $\begin{array}{l}\text { Monte Carlo } \\
\text { simulation to estimate } \\
\text { a systemic risk } \\
\text { measure, followed by } \\
\text { linear and nonlinear } \\
\text { Granger causality tests }\end{array}$ & $\begin{array}{l}\text { There is a bidirectional } \\
\text { causality between banks } \\
\text { and insurances, but the } \\
\text { effect of banks on } \\
\text { insurances is longer- } \\
\text { lasting and stronger than } \\
\text { vice versa. }\end{array}$ \\
\hline $\begin{array}{l}\text { Goldsmith- } \\
\text { Pinkham \& } \\
\text { Yorulmazer } \\
\text { (2010) }\end{array}$ & $\begin{array}{l}\text { Did the Northern } \\
\text { Rock bank run lead to } \\
\text { spillover effects in } \\
\text { the banking system } \\
\text { and which bank } \\
\text { characteristics caused } \\
\text { abnormal returns? }\end{array}$ & $\begin{array}{l}---- \\
\end{array}$ & $\begin{array}{l}\text { Returns on } \\
\text { stock prices of } \\
\text { the ten largest } \\
\text { UK banks } \\
\text { (September } 14, \\
2007 \text { to } \\
\text { September } 17 \text {, } \\
\text { 2007) } \\
\end{array}$ & $\begin{array}{l}\text { Event-study using } \\
\text { OLS regression }\end{array}$ & $\begin{array}{l}\text { Significant spillover } \\
\text { effects due to the } \\
\text { investors' rational } \\
\text { response to the illiquidity } \\
\text { of the wholesale funding } \\
\text { market }\end{array}$ \\
\hline $\begin{array}{l}\text { Poirson \& } \\
\text { Schmittmann } \\
(2013)\end{array}$ & $\begin{array}{l}\text { Do clusters of } \\
\text { linkages between } \\
\text { banks exist beyond } \\
\text { market risk factors? }\end{array}$ & ----- & $\begin{array}{l}\text { Daily stock } \\
\text { returns and } \\
\text { bank indicators } \\
\text { of } 83 \text { banks } \\
\text { from } 21 \\
\text { countries } \\
\text { (December } \\
2002 \text { to } \\
\text { November } \\
2011 \text { ) }\end{array}$ & $\begin{array}{l}\text { Estimation of a factor } \\
\text { model of return, OLS } \\
\text { regression }\end{array}$ & $\begin{array}{l}\text { Sock returns of German } \\
\text { banks co-move with other } \\
\text { German banks, UK and } \\
\text { U.S. banks; UK banks } \\
\text { additionally correlate } \\
\text { with other European, U.S. } \\
\text { and Asian banks }\end{array}$ \\
\hline
\end{tabular}




\section{Appendix B.1. Spillover Coefficients}

The following tables present the estimation results for the spillover coefficients for Germany and the UK employing REIT indices as additional control variables, but resorting to a shorter observation period (January 1, 2007 to July 27, 2015). Additionally, the quantile representing economic distress of an institution was set to $10 \%$ and $15 \%$. Overall, the results for both, Germany and the UK, are very similar independently of the quantile chosen. It can also be asserted that the shorter period does not qualitatively alter the results. This is most probably due to the fact that the excluded period 2003 to 2006 was characterised by tranquillity of the financial markets and thus the modification would solely influence the results for tranquil quantiles (Adams et al., 2014a). These, however, stay robust as shown by Appendix B.1 and Appendix B.2 due to their generally low values.

\section{Appendix B.1: Spillover Coefficients for Germany including REIT Index and different quantiles}

\begin{tabular}{|c|c|c|c|c|c|c|c|c|}
\hline & & \multicolumn{3}{|c|}{$\begin{array}{l}\text { Spillover-originating institution (spillover } \\
\text { vector B) }\end{array}$} & \multicolumn{4}{|c|}{ Control variables } \\
\hline \multicolumn{2}{|c|}{$\begin{array}{l}\text { Spillover-receiving } \\
\text { institution }\end{array}$} & Banks & Insurances & Hedge funds & $\begin{array}{l}\text { GSCI } \\
\text { index }\end{array}$ & $\begin{array}{l}\text { REIT } \\
\text { index }\end{array}$ & $\begin{array}{l}\text { Non-financial } \\
\text { index }\end{array}$ & $\begin{array}{l}\text { Lagged } \\
\operatorname{VaR}\end{array}$ \\
\hline \multirow{3}{*}{$\begin{array}{l}\text { Tranquil } \theta= \\
0.75\end{array}$} & Banks & - & 0.0007 & 0.0185 & 0.0051 & 0.0010 & -0.0081 & $0.9492 * * *$ \\
\hline & Insurances & 0.0060 & - & $0.0431 *$ & 0.0017 & -0.0012 & 0.008 & 0.9241 *** \\
\hline & $\begin{array}{l}\text { Hedge } \\
\text { funds }\end{array}$ & -0.0004 & -0.0011 & - & 0.0008 & -0.0002 & 0.0010 & $0.9036 * * *$ \\
\hline \multirow{3}{*}{$\begin{array}{l}\text { Normal } \theta= \\
0.5\end{array}$} & Banks & - & 0.0090 & $0.0808^{*}$ & -0.0031 & 0.0102 & -0.0041 & $0.9633^{* * *}$ \\
\hline & Insurances & 0.0052 & - & 0.0560 & 0.0045 & 0.0024 & 0.0004 & 0.9481 *** \\
\hline & $\begin{array}{l}\text { Hedge } \\
\text { funds }\end{array}$ & -0.0017 & 0.0009 & - & -0.0003 & 0.0011 & 0.0007 & $0.9457 * * *$ \\
\hline \multirow{3}{*}{$\begin{array}{l}\text { Volatile } \theta= \\
0.15\end{array}$} & Banks & - & $0.0659^{* *}$ & 0.1536 & -0.0009 & $0.0345^{* * * *}$ & -0.0261 & $0.9853^{* * * *}$ \\
\hline & Insurances & 0.0052 & - & 0.0829 & 0.0060 & 0.0025 & 0.0080 & $1.0233^{*} * *$ \\
\hline & $\begin{array}{l}\text { Hedge } \\
\text { funds }\end{array}$ & -0.0001 & 0.0027 & - & -0.0001 & $0.0033^{*}$ & $-0.0082 * *$ & $1.0689 * * *$ \\
\hline \multirow{3}{*}{$\begin{array}{l}\text { Volatile } \theta= \\
0.125\end{array}$} & Banks & - & $0.0621^{*}$ & 0.2209 & 0.0083 & 0.0226 & -0.0296 & $1.0039 * * *$ \\
\hline & Insurances & 0.0057 & - & 0.1417 & 0.0076 & -0.0007 & 0.0062 & $1.0342 * * *$ \\
\hline & $\begin{array}{l}\text { Hedge } \\
\text { funds }\end{array}$ & -0.0011 & 0.0042 & - & -0.0010 & 0.0035 & $-0.0082 * *$ & $1.0758 * * *$ \\
\hline \multirow{3}{*}{$\begin{array}{l}\text { Volatile } \theta= \\
0.1\end{array}$} & Banks & - & $0.0739 *$ & $0.2896^{*}$ & -0.0013 & 0.0306 & -0.0102 & $1.0176^{* * *}$ \\
\hline & Insurances & 0.0193 & - & $0.2853 * * *$ & 0.0126 & -0.0105 & 0.0067 & $1.0256^{* * * *}$ \\
\hline & $\begin{array}{l}\text { Hedge } \\
\text { funds }\end{array}$ & -0.0019 & 0.0022 & - & 0.0021 & 0.0025 & $-0.0085^{* *}$ & $1.0964 * * *$ \\
\hline
\end{tabular}




\section{Appendix B.2: Spillover Coefficients for the UK including REIT index and different}

quantiles

\begin{tabular}{|c|c|c|c|c|c|c|c|c|}
\hline \multirow{2}{*}{\multicolumn{2}{|c|}{$\begin{array}{l}\text { Spillover-receiving } \\
\text { institution }\end{array}$}} & \multicolumn{3}{|c|}{$\begin{array}{l}\text { Spillover-originating institution (spillover } \\
\text { vector B) }\end{array}$} & \multicolumn{4}{|c|}{ Control variables } \\
\hline & & Banks & Insurances & Hedge funds & $\begin{array}{l}\text { GSCI } \\
\text { index }\end{array}$ & $\begin{array}{l}\text { REIT } \\
\text { index }\end{array}$ & $\begin{array}{l}\text { Non-financial } \\
\text { index }\end{array}$ & $\begin{array}{l}\text { Lagged } \\
\operatorname{VaR}\end{array}$ \\
\hline \multirow{3}{*}{$\begin{array}{l}\text { Tranquil } \theta= \\
0.75\end{array}$} & Banks & - & -0.0037 & 0.0450 & -0.0020 & 0.0063 & 0.0149 & $0.9322 * * *$ \\
\hline & Insurances & $0.0153 * * *$ & - & 0.0599 & -0.0021 & -0.0113 & 0.0051 & $0.9097 * * *$ \\
\hline & $\begin{array}{l}\text { Hedge } \\
\text { funds }\end{array}$ & 0.0001 & -0.0007 & - & 0.0006 & -0.0000 & 0.0005 & $0.9010 * * *$ \\
\hline \multirow{3}{*}{$\begin{array}{l}\text { Normal } \theta= \\
0.5\end{array}$} & Banks & - & -0.0053 & 0.0679 & 0.0073 & 0.0077 & 0.0088 & $0.9624 * * *$ \\
\hline & Insurances & $0.0312 * * *$ & - & 0.0852 & 0.0050 & -0.0079 & -0.0057 & $0.9210^{* * * *}$ \\
\hline & $\begin{array}{l}\text { Hedge } \\
\text { funds }\end{array}$ & -0.0006 & 0.0010 & - & 0.0006 & -0.0003 & -0.0001 & $0.9424 * * *$ \\
\hline \multirow{3}{*}{$\begin{array}{l}\text { Volatile } \theta= \\
0.15\end{array}$} & Banks & - & -0.0198 & 0.2178 & 0.0399 & 0.0056 & -0.0283 & $1.0651 * * *$ \\
\hline & Insurances & $0.0458 * *$ & - & 0.1120 & 0.0221 & -0.0068 & 0.0071 & $0.9636^{* * * *}$ \\
\hline & $\begin{array}{l}\text { Hedge } \\
\text { funds }\end{array}$ & -0.0015 & -0.0011 & - & -0.0016 & $0.0039 *$ & 0.0003 & $1.0622 * * *$ \\
\hline \multirow{3}{*}{$\begin{array}{l}\text { Volatile } \theta= \\
0.125\end{array}$} & Banks & - & $-0.0413 * *$ & $0.4131 *$ & $0.0429 *$ & 0.0133 & -0.0292 & $1.0774 * * *$ \\
\hline & Insurances & $0.0491 * *$ & - & 0.1428 & $0.0408 * *$ & $-0.0331 *$ & 0.0137 & $0.9848 * * *$ \\
\hline & $\begin{array}{l}\text { Hedge } \\
\text { funds }\end{array}$ & -0.0023 & 0.0003 & - & 0.0003 & 0.0037 & -0.0019 & $1.0804 * * *$ \\
\hline \multirow[t]{3}{*}{$\begin{array}{l}\text { Volatile } \theta= \\
0.1\end{array}$} & Banks & - & $-0.0645 * *$ & 0.3628 & $0.0581 * *$ & 0.0031 & 0.0079 & $1.0899 * * *$ \\
\hline & Insurances & $0.0470 * *$ & - & 0.1996 & $0.0406^{*}$ & -0.0218 & -0.0044 & $0.9955^{* * *}$ \\
\hline & $\begin{array}{l}\text { Hedge } \\
\text { funds }\end{array}$ & $-0.0036^{* *}$ & -0.0000 & - & 0.0010 & $0.0055^{*}$ & -0.0018 & $1.0843 * * *$ \\
\hline
\end{tabular}

